\title{
Memórias na sala de aula: análise de uma prática pedagógica na perspectiva do letramento literário
}

\begin{abstract}
Resumo
$\mathrm{O}$ artigo tem por objetivo apresentar e analisar um trabalho de letramento literário, de leitura e produção textual, realizado com alunos do $3^{\circ}$ ano do ensino fundamental de uma escola pública estadual da cidade de São João del Rei, em Minas Gerais. Subsidiaram teoricamente a pesquisa estudos sobre a leitura e o letramento literários desenvolvidos nas últimas décadas, bem como sobre a produção textual na escola. A prática analisada mostra que foi feito um trabalho produtivo e eficaz com o livro de relatos de memória Histórias de avô e avó, de Arthur Nestrovski, mas que poderia ter avançado mais caso não houvesse certas limitações de formação e circunstâncias do trabalho docente.
\end{abstract}

Palavras-chave: Leitura - estudo e ensino. Letramento. Letramento literário.

\section{Ana Caroline de Almeida}

Universidade Federal de

Pernambuco - UFPE - Brasil karolyne_jv@yahoo.com.br

Hércules Tolêdo Corrêa

Universidade Federal de Ouro Preto - UFOP - Brasil

herculest@uol.com.br

\section{Para citar este artigo:}

ALMEIDA, Ana Caroline de; CORRÊA, Hércules Tolêdo. Memórias na sala de aula: análise de uma prática pedagógica na perspectiva do letramento literário. Revista Linhas. Florianópolis, v. 18, n. 37, p. 108-130, maio/ago. 2017. 


\title{
Memories in the classroom: analysis of a pedagogical practice in the perspective of literary literacy
}

\begin{abstract}
The article aims to present and analyze a pedagogical practice of literary literacy, reading and textual production, carried out with students of the third year of elementary school in a state public school in the city of São João del Rei, in Minas Gerais. The research is theoretically grounded in studies about literary reading and literacy developed in recent decades, as well as in studies about textual production in school. The analyzed practice shows that a productive and effective work was undertaken with Arthur Nestrovsky's Histórias de avô e avó, and that it could, however, have advanced further if there were not certain limitations in training and certain constraints on the teaching practice.
\end{abstract}

Keywords: Reading - Study and Teaching. New Literacy. Literary Literacy. 
O letramento literário, como outros tipos de letramento, continua sendo uma apropriação pessoal de práticas sociais de leitura/escrita, que não se reduzem à escola, embora passem por ela. A experiência estética, dentre as quais se inclui a leitura literária, está sendo mais valorizada agora, como modo de reumanizar as relações enrijecidas pela absolutização de mercadorias. (PAULINO, 2010, p. 165)

De acordo com dados do INAF - Indicador de Alfabetismo Funcional, na sua edição de $2010-2011$, somente $62 \%$ da população com ensino superior e $35 \%$ das pessoas com ensino médio completo foram consideradas plenamente alfabetizadas. Um em cada quatro brasileiros que cursam ou cursaram o Ensino Fundamental II ainda foram classificados no nível rudimentar da alfabetização. Esses dados apontam para um número alarmante de analfabetos funcionais espalhados pelo país. ${ }^{1}$

Nas palavras de Rojo (2004), “a maior parcela de nossa população, embora hoje possa estudar, não chega a ler. A escolarização, no caso da sociedade brasileira, não leva à formação de leitores e produtores de texto proficientes e eficazes, e, às vezes, chega mesmo a impedi-la." Essa é uma constatação não só da autora, mas também de outros pesquisadores da área e atestada em diversos exames, como ENEM, SAEB e PISA ${ }^{2}$, que apresentam resultados bastante insuficientes para o uso social da leitura e da escrita, numa sociedade grafocêntrica como a nossa.

Tais constatações têm mobilizado ações de professores da educação básica, gestores, pesquisadores, sociedade civil e governos no sentido de melhorar o retrato que temos ainda hoje da escolarização no país. Para Kleimam (2008, p. 480), "temos presenciado uma situação de efervescência no Brasil, no que diz respeito à produção de

\footnotetext{
1 O INAF constitui uma pesquisa realizada pelo Instituto Paulo Montenegro e Ação Educativa e tem por objetivo produzir informações que sirvam para fomentar e qualificar o debate público sobre a qualidade da educação. Os dados completos da edição citada (2010-2011) estão disponíveis em: <http://www.ipm.org.br/pt-br/programas/inaf/relatoriosinafbrasil/Paginas/inaf2011_2012.aspx>. Acesso em: 06 de março de 2017.

2 Esses exames constituem avaliações oficiais de caráter nacional e internacional que visam o monitoramento das instituições de ensino. Mais informações podem ser acessadas nos seguintes sites: <http://portal.inep.gov.br/pisa; http://portal.mec.gov.br/component/tags/tag/31992>. Acesso em: 06 de março de 2017.
} 
documentos governamentais - Leis, normas e preceitos - destinados a regular e melhorar o Ensino Fundamental e médio no país". Exemplo disso é a consolidação do Ensino Fundamental com nove anos de duração, uma prioridade do Plano Nacional de Educação PNE (2014); O Programa Nacional do Livro Didático (PNLD), que seleciona e leva às escolas livros didáticos com melhor qualidade e o Programa Nacional Biblioteca da Escola (PNBE), responsável pela ampliação dos acervos literários das bibliotecas escolares.

Mais recentemente, o governo federal, estados e municípios assumiram um acordo formal para firmar o compromisso de garantir o direito à alfabetização plena a todas as crianças até, no máximo, oito anos de idade, ou seja, ao final do ciclo inicial de alfabetização. Este acordo, denominado Pacto Nacional pela Alfabetização na Idade Certa - PNAIC, pode ser compreendido como a iniciativa política mais recente para os anos iniciais do EF, buscando garantir a melhoria dos resultados da alfabetização no Brasil, por meio de: a) formação continuada presencial para os professores alfabetizadores, que, de acordo com o caderno de apresentação do programa, está centrada na prática do professor, de modo que as singularidades do trabalho pedagógico sejam objeto de reflexão; b) Materiais didáticos variados, incluindo a distribuição de acervos de livros infantis para as turmas de $1^{\circ}$ ao $3^{\circ}$ ano; c) Avaliações sistemáticas, com a introdução da Avaliação Nacional da Alfabetização (ANA) para alunos do $3^{\circ}$ ano; d) Gestão, controle social e mobilização, por meio do SISPACTO. ${ }^{3}$

Não podemos negar que iniciativas dessa natureza têm impactado as práticas pedagógicas de alfabetização no país, em níveis diferenciados, a depender das apropriações que os professores alfabetizadores fazem das propostas apresentadas. No caso dos programas de incentivo à leitura, é inegável, por exemplo, que acervos literários disponibilizados para as salas de aulas do $1^{\circ}$ ao $3^{\circ}$ ano potencializaram o trabalho com o letramento literário na escola.

Nesta esteira, o que vem pautando as discussões em torno da alfabetização no país refere-se às metodologias e estratégias que têm sido utilizadas pelos docentes para o ensino da leitura e da escrita e quais seriam aquelas mais indicadas para a formação do leitor e produtor de textos. Ainda que existam disputas teóricas no campo da

\footnotetext{
3 O SISPACTO constitui um sistema de monitoramento do <http://pacto.mec.gov.br/31-outros-destaques/79-entenda-o-sispacto>.

PNAIC. Mais informações em:
} 
alfabetização, é possível afirmar que há certo consenso de que a alfabetização precisa ocorrer na perspectiva do letramento.

Mas o que é alfabetizar na perspectiva do letramento? Não é nosso objetivo, aqui, pensar na complexidade conceitual que envolve os termos alfabetização e letramento, até porque esta é uma discussão bem mais ampla. De modo simplificado, podemos dizer que alfabetizar na perspectiva do letramento é possibilitar às crianças compreender o funcionamento do sistema de escrita alfabético por meio de situações reais de uso da língua. É também desenvolver habilidades de leitura e escrita tendo como suporte diferentes gêneros textuais. Em outras palavras, é levar a criança à apropriação da escrita como objeto cultural. Para Ferreiro (2011, p. 99), “a língua escrita é muito mais que um conjunto de formas gráficas, é um modo de a língua existir, é um objeto social, é parte do nosso patrimônio cultural." Quando a criança se apropria da escrita como objeto cultural, ela se torna apta a usá-la socialmente, em contextos variados e de maneira competente.

Além disso, nos Parâmetros Curriculares Nacionais de Língua Portuguesa - PCN, a concepção teórica de linguagem é marcada pela noção de gêneros do discurso. Os gêneros orais e escritos, definidos como tipos relativamente estáveis de enunciados, pertencentes a diferentes esferas da atividade humana (BAKHTIN, 1992), precisam ser eleitos como objeto de ensino, numa proposta de alfabetização que se proponha à formação de usuários competentes da língua oral e escrita. Mais que isso, o trabalho com gêneros do discurso se insere numa perspectiva de ensino e aprendizagem que concebe a língua/linguagem como produtora de sentidos. Afinal, é pela mediação da linguagem que a criança aprende os sentidos atribuídos pela cultura às coisas, ao mundo e às pessoas.

Nessa direção, este artigo apresenta uma prática pedagógica de alfabetização na perspectiva do letramento, fundamentada numa concepção de linguagem calcada nos pressupostos bakhtinianos e que teve como mote a leitura e o letramento literário na escola. Para tanto, o texto se organiza em três partes: na primeira, caracterizamos brevemente a escola e apresentamos a fundamentação teórica subjacente ao trabalho desenvolvido. Na segunda, descrevemos como se deu o desenvolvimento do projeto Histórias de avô e avó e, por fim, tecemos algumas considerações que julgamos mais relevantes. 


\section{O ponto de partida}

A prática relatada e analisada a seguir ocorreu na Escola Estadual Deputado Mateus Salomé, localizada no bairro Matozinhos, na cidade mineira de São João del Rei. A cidade começou a se constituir por volta do ano de 1700, exatamente onde hoje se localiza o bairro de Matozinhos, atualmente o segundo centro comercial da cidade, com vários estabelecimentos e serviços, garantindo aos moradores uma vida bastante autônoma e independente de outras regiões da cidade.

Esta escola faz parte da Rede Estadual de Ensino de Minas Gerais, e no ano de 2014 atendia cerca de 300 alunos, do $1^{\circ}$ ao $5^{\circ}$ ano, com faixa etária entre seis e dez anos de idade. Esses alunos se distribuíam em 14 turmas: nove delas no turno da tarde e cinco no turno da manhã. Os professores mais experientes atuavam no turno matutino e os mais jovens no vespertino. Todos tinham curso superior, à época. Os mais experientes contavam, também, com cursos de especialização em diferentes áreas.

Os educandos atendidos pela escola eram, em sua maioria, interessados e participativos, assim como suas famílias, que acompanhavam a vida escolar dos filhos, participando de reuniões de pais e eventos realizados pela escola. A turma na qual foi realizada a prática tinha também este perfil: um $3^{\circ}$ ano do Ensino Fundamental I, com 23 alunos, na faixa etária entre oito e nove anos, bastante interessados, frequentes e participativos. Normalmente, se envolviam com todas as propostas de atividades. Sabemos, entretanto, que a participação em atividades culturais como cinema, teatro ou outros eventos, como festivais de música ou de arte em geral, não era comum para eles. Também a leitura literária não constitui prática cultural comum a essas famílias, pois não são famílias leitoras nem contam com muitos livros em casa. Cabia mesmo à escola desenvolver atividades que proporcionassem a eles o envolvimento com práticas de leitura literária e outras atividades que visassem à formação integral dessas crianças.

O diagnóstico realizado nos primeiros meses de aula indicou que certos procedimentos e capacidades para a leitura e para a escrita já tinham sido alcançados por aquele grupo. As crianças já apresentavam muitas habilidades, tais como: compreender diferenças entre a escrita e outras formas gráficas; dominar as convenções gráficas; conhecer o alfabeto; compreender a natureza alfabética do nosso sistema de escrita; 
dominar as relações entre grafemas e fonemas; saber ler e escrever palavras e frases; saber ler textos escritos; saber ler, reconhecendo globalmente as palavras. Mas isso ainda era pouco.

Partindo do pressuposto de que a escrita é um objeto cultural e que a escola precisa ajudar as crianças a se apropriarem deste objeto como tal, e mais, que ser letrado e ler na vida e na cidadania é "escapar da literalidade dos textos e interpretá-lo, colocando-os em relação com outros textos e discursos, de maneira situada na realidade social; é discutir com os textos, replicando e avaliando posições e ideologias que constituem seus sentidos; é, enfim, trazer o texto para a vida e colocá-lo em relação com ela" (ROJO, 2004, p. 2), é que todo o trabalho de leitura e escrita dessa turma foi organizado por meio de projetos, tendo como mote principal a leitura e o letramento literários.

Nos últimos anos, a literatura na escola tem sido bastante incentivada. Primeiro porque a literatura, por si só, ocupa um lugar único em relação à linguagem, como muitos defendem. Nas palavras de Cosson (2006, p. 17) “cabe à literatura tornar o mundo compreensível, transformando a sua materialidade em palavras de cores, odores, sabores e formas intensamente humanas". Depois, segundo o mesmo autor, os textos literários proporcionam uma forma privilegiada de inserção no mundo da escrita.

Mas a literatura na escola também tem sido criticada. Afinal, a escolarização da literatura é inevitável, como bem indica Soares (2011), pois a escola possui características peculiares no modo de organizar e transmitir o conhecimento historicamente acumulado pela humanidade, o que faz com que qualquer saber dentro da escola se torne um "saber escolar" e se escolarize. A questão que se coloca é como escolarizar um saber de maneira adequada? No caso da literatura infantil, a partir de 1970, vários pesquisadores passaram a se ocupar com estudos desse campo do conhecimento e mais recentemente muitos materiais têm sido produzidos, a fim de levar aos professores da educação básica conhecimentos teóricos e práticos para uma adequada escolarização da literatura.

Exemplo disso é o livro Leitura literária na escola: reflexões e propostas na perspectiva do letramento, organizado por Renata Junqueira de Souza e Berta Lúcia Tagliari Feba (2011), que traz uma série de artigos, com autores variados, discutindo atividades e abordagens alternativas de muitos gêneros na escola. Este livro faz parte do 
acervo do PNBE do Professor - 2013 e serviu de subsídio para o planejamento e desenvolvimento da prática pedagógica apresentada e analisada neste artigo.

Ao utilizar de maneira adequada os textos e livros literários para o ensino sistemático da leitura e da escrita, o professor certamente estará contribuindo para a formação de bons leitores e produtores de texto. Ao passo que, uma inadequada escolarização desse objeto tem sido responsável, muitas vezes, por produzir um efeito contrário do que se espera, levando a criança a criar certa aversão ao livro literário.

\section{Apresentando e analisando a prática pedagógica}

A leitura literária teve lugar garantido na turma em dois momentos específicos e com características distintas. No início da aula, a professora escolhia diariamente um livro do acervo do cantinho da leitura da sala de aula e lia para as crianças. Chamamos a essa estratégia didática de leitura compartilhada. Ao final da aula, as crianças tinham oportunidade de escolher o quê (materiais poderiam ser trazidos de casa) e como gostariam de ler (individualmente, em duplas, ou para grupo). Chamamos a essa estratégia de leitura livre. ${ }^{4}$

Além disso, ao longo do ano 2014, foram organizados quatro projetos literários para realizar um trabalho mais sistemático de leitura e escrita com a turma. Os projetos ganhavam o nome dos livros literários utilizados como mote para o trabalho. Foram eles: De carta em carta, de Ana Maria Machado, nos meses de março e abril; Histórias de avô e avó, de Arthur Nestrovski, entre maio e junho; Viviana, a Rainha do pijama, de Steve Webb e Luciano Vieira Machado, em agosto e setembro; e Os animais fantásticos, de José Jorge Letria e André Letria, no final do ano.

Neste texto contemplamos o trabalho realizado a partir do livro Histórias de avô e avó, do crítico e professor de música Arthur Nestrovsky, composto por seis relatos de memória. O livro integra a coleção "Memória e História” da editora Companhia das Letrinhas e relata situações entre o autor/narrador e seus antepassados, de origem judaica russa.

\footnotetext{
${ }^{4}$ Para uma visão dos vários conceitos de leitura, sugerimos os verbetes do Glossário CEALE - Termos de Alfabetização, Leitura e Escrita para educadores.
} 
Como não havia livros suficientes para todas as crianças, foram feitas cópias para cada uma delas. O projeto foi organizado em dois grandes momentos, um com foco na leitura e outro com foco na escrita.

\section{As rodas de leitura e conversa}

As rodas de leitura e conversa constituem estratégias pedagógicas que podem auxiliar o docente em várias áreas. Uma delas é o trabalho de letramento literário, relatado neste artigo. Conforme Corrêa (2014, p. 291), uma roda de leitura é uma prática pedagógica e cultural relacionada ao ato de ler conjuntamente, muito utilizada com leitores em formação (crianças da educação infantil e séries iniciais do ensino fundamental). Normalmente, os chamados mediadores de leitura (professores, contadores de história, bibliotecários e outros profissionais ou pessoas envolvidas com a temática) leem com ou para os demais. Embora comumente seja realizada em círculo daí o nome de roda -, essa prática admite que os participantes se coloquem em semicírculos ou que fiquem deitados em tapetes ou colchonetes.

Na primeira semana, para começar o trabalho com o livro Histórias de avô e avó, do gênero relato de memória, foi organizada uma roda de conversa na sala, informando aos alunos que naquele momento certas experiências vividas seriam tomadas para reflexão. “Trataríamos de situações diversas que, por algum motivo, tivessem nos marcado", como relata a professora da turma. Os alunos, de início, ficaram tímidos, mas depois de ouvirem algumas memórias da infância da professora acabaram se soltando e contaram experiências incríveis e diversas.

Em certo momento, a professora afunilou a conversa dizendo a eles que, a partir dali, os relatos deveriam envolver avô ou avó. Mais uma vez, a professora abriu a conversa relatando algumas experiências com seus avós paternos, com os quais teve mais contato na infância. Novamente, as crianças ficaram mais à vontade para realizar seus relatos orais sobre experiências com avôs ou avós.

Na segunda semana, também com a turma em círculo, foi apresentado o livro Histórias de avô e avó. Explorou-se a capa: ilustrações e outras informações. Os alunos foram indagados sobre qual seria o assunto abordado naquele livro. As crianças 
levantaram hipóteses sobre o conteúdo do livro. Depois da capa, passou-se à autoria do livro. A professora perguntou se eles conheciam quem era o autor. Os alunos disseram que não conheciam. Sugeriu então uma pesquisa sobre a vida do autor. Esta pesquisa foi apresentada no dia seguinte, que além desta atividade, contou com a exploração de mais algumas páginas do livro: a dedicatória e o sumário. A função dessas partes do livro foi discutida e testada, de maneira prática, identificando a página onde estava determinado texto.

A professora optou por não ler nenhum texto nesse dia. Comentou sobre o projeto que seria desenvolvido com o livro. Explicou que o livro ajudaria a aprender muita coisa e que trabalharia com ele um pouco a cada semana. Ela destacou que as narrativas do livro ajudariam a turma a compreender como é um relato de memória e qual a função desse gênero. Nessa hora, captou dos alunos quais conhecimentos eles já traziam sobre o gênero relato, com perguntas como: "Vocês já leram algum texto que relatasse uma experiência vivida?”, “Que contasse de alguma coisa que aconteceu com alguém?”. A professora explicou ainda que, à semelhança do trabalho realizado a partir do livro De carta em carta, o projeto com este livro também culminaria com uma produção deles e passaram, então, a organizar melhor o projeto.

Esta atividade de organização do projeto não era novidade para a turma, já que outros projetos, a partir de livro literário, tinham sido desenvolvidos naquele ano, como, por exemplo, o projeto De carta em carta. Então, reafirmaram acordos discutidos anteriormente, relativos ao comportamento e disciplina necessários e aos instrumentos utilizados para correção dos textos; e decidiram que usariam o livro nas aulas de português e que o produto final seria um livro para o acervo da sala.

Na semana seguinte, continuaram com as rodas. Dessa vez, foi uma roda de leitura. Foi lido o texto "O ábaco do vô Felipe”, escolhido pelas crianças. Explorou-se a ilustração. Depois um aluno realizou a leitura do texto. Os alunos puderam então confirmar algumas de suas hipóteses iniciais sobre o livro. Fizeram alguns questionamentos estimulados pela história, que lembrava a fuga de muitos judeus na época em que foram perseguidos. Com o auxílio de um mapa, a professora trabalhou a localização da Ucrânia e da Rússia e a posição desses países em relação ao Brasil. Conforme combinado anteriormente, os alunos realizaram a pesquisa sobre o autor e, 
neste dia, compartilharam com os colegas as informações que encontraram. A professora também pesquisou e compartilhou o que descobriu sobre o autor. Além disso, leram as informações que o livro trazia sobre ele. Todas essas discussões foram relacionadas com as primeiras aulas da turma, quando os alunos leram e produziram textos autobiográficos, possibilitando um contraste entre biografias e autobiografias. A essa altura, Arthur Nestrovski já podia ser considerado "um amigo da turma”.

Na quarta semana, foram lidos dois relatos do livro: "Uma aula de música do meu avô" e "O vô Maurício e os livros". Exploraram-se o título e as ilustrações de cada texto, de onde emergiram algumas ideias. Essas duas histórias impulsionaram a conversa sobre a relação que as crianças tinham com seus avôs e avós. As crianças puderam comentar coisas interessantes que não haviam sido comentadas na primeira roda. Caio, um aluno bastante ativo, fez um comentário interessante sobre a avó dele: "Eu gosto muito da minha vó, porque ela sempre me salva da minha mãe". Essa fala rendeu boas risadas e uma boa conversa sobre essas relações afetivas que normalmente estabelecemos com avôs e avós. Os ensinamentos e as aprendizagens que constantemente vivenciamos com nossos avós e o quanto o autor do texto, Arthur Nestrovski, tinha aprendido com o avô Maurício também foram objeto de reflexão. As crianças foram indagadas sobre coisas que elas haviam aprendido com seus avós.

O dia foi finalizado com uma proposta de atividade escrita. Em duplas, as crianças deveriam escrever um e-mail para o escritor. Nesta mensagem deveriam relatar o que acharam da relação dele com o avô, a partir da leitura e discussão dos textos. Podiam ainda comentar sobre o projeto que estavam desenvolvendo. A ideia era simular a escrita de um e-mail, pois já haviam trabalhado esse gênero no primeiro projeto. A professora fez intervenções pontuais durante a atividade e, ao final, as duplas leram para a turma os textos que produziram.

Na quinta semana já era momento de sistematizar os conhecimentos. Depois da leitura e discussão de três relatos de memória de Arthur Nestrovski, a roda de conversa foi organizada mais uma vez para tratar mais especificamente das características do gênero. Os alunos foram instigados a pensar sobre quais as características e a função do gênero relato de memória. Depois que os alunos comentaram, a conversa foi sistematizada e explicitou-se que, nesse gênero textual, as pessoas registram situações 
vivenciadas por elas, relacionadas com períodos específicos das suas vidas, em espaços determinados e com temas pontuais. Estes aspectos foram então buscados nas histórias de Nestrovski. Quais experiências ele havia vivido? Em qual período da sua vida? Onde essas experiências aconteceram? Qual o tema central dos relatos do autor? Os alunos relembraram trechos e elementos da narrativa que demarcavam esses aspectos. A finalidade da narrativa, concluiu a turma, seria "contar alguma coisa que aconteceu com a gente". De fato é isso, escrever narrativas desse tipo é compartilhar experiências e organizar a memória sobre certos aspectos da nossa vida.

Depois, tratou-se dos elementos de composição de um relato: o uso da primeira pessoa, descrições de fatos, pessoas ou lugares e impressões pessoais do autor. As crianças voltaram aos textos para encontrar essas marcas e reler trechos. Refletiu-se com os alunos sobre as relações entre os fatos relatados e o tempo histórico, outra característica importante do gênero.

Depois disso, foi a vez da leitura individual e silenciosa dos textos "A bênção da bisa" e "Os bolinhos de peixe da vó Póli". Após essa leitura silenciosa, veio a leitura em voz alta. A partir daí, houve uma confrontação coletiva desses relatos. Os alunos expuseram suas compreensões e indagações. A professora fez outros questionamentos, objetivando levar as crianças a compreenderem melhor as narrativas. Por fim, foi registrada no quadro a síntese dos sentidos e significados construído pelos alunos, a partir dos dois textos.

Ao final, os comentários iniciais sobre as características do gênero foram retomados. A discussão sobre a descrição nos relatos de memória foi ampliada. "Qual a finalidade de se descrever pessoas, coisas ou lugares num relato?". Foi com essa pergunta que a professora buscou compreender, com os alunos, esse elemento de composição dos relatos. Foi destacado o lugar do leitor, que precisa compreender com clareza o que se quer relatar. A descrição ajuda a levar o leitor para o tempo e espaço do acontecido. Alguns trechos descritivos nos relatos foram relidos com as crianças de olhos fechados, imaginando os lugares e as pessoas, na tentativa de levá-las a perceber como a descrição auxilia o leitor a uma compreensão mais apurada da narrativa.

Este primeiro momento do projeto contemplou a compreensão coletiva do gênero e dos textos lidos. Buscamos propor atividades variadas como: situar o texto no projeto e 
no seu contexto, leituras individuais e silenciosas, confrontação entre os textos pelos pares e síntese do significado dos textos (GIROTTO; REVOREDO, 2011).

Estas estratégias tiveram alguns objetivos específicos. Nas rodas de leitura e conversa, por exemplo, as crianças puderam desenvolver a questão da oralidade, além de ampliar a capacidade leitora, desenvolvendo: capacidades de compreensão - ativação de conhecimentos de mundo, antecipação ou predição de conteúdos ou propriedades dos textos, checagem de hipóteses, localização e/ou cópia de informações, comparação de informações, generalização, produção de inferências locais, produção de inferências globais; e capacidades de apreciação e réplica do leitor em relação ao texto recuperação do contexto de produção do texto, definição de finalidades e metas da atividade de leitura, percepção de relação de intertextualidade, percepção de relações de interdiscursividade, percepção de outras linguagens, elaboração de apreciações estéticas e/ou afetivas, elaboração de apreciações relativas a valores éticos e/ou políticos (ROJO, 2004).

Essas rodas possibilitaram também uma aproximação das crianças com o gênero relato de memória: conhecer as suas características; reconhecer os elementos de composição de um relato (uso da primeira pessoa, descrições e impressões pessoais do autor) e perceber as relações entre os fatos relatados e o tempo histórico.

As ações conjuntas da professora e dos alunos, nas atividades de leitura propostas, levam ao que podemos chamar de letramento literário, o que se diferencia, em termos teóricos e conceituais, da simples leitura da literatura ou da leitura literária. Enquanto a leitura da literatura pressupõe apenas estratégias de compreensão de um texto sem levar em conta as suas especificidades literárias, enquanto objeto estético, e a leitura literária, embora já reconheça no texto as suas qualidades artísticas, o letramento literário avança na medida em que tem por objetivo explorar o texto literário de forma consciente, buscando relações entre o texto literário e paratextos (orelhas, prefácio, quarta capa); proporcionando também o conhecimento do contexto (quem é o autor, não só a biografia, mas a sua inserção no universo social e literário) e também estabelecendo relações intertextuais, como as comparações entre os diversos relatos presentes no mesmo livro, ou até mesmo entre os relatos do livro e outros relatos. 
Portanto, esse trabalho de letramento literário se faz por meio da leitura, compreensão e análise textual, de uma análise contextual e também intertextual.

De acordo com Cosson, não há apenas uma maneira de se efetivar o letramento literário, mas há quatro características que Ihe são fundamentais. Em primeiro lugar, é preciso que o aluno tenha contato direto com o texto literário. Em segundo lugar, é preciso construir uma comunidade de leitores. Se o letramento literário está ocorrendo na escola, a sala de aula precisa se constituir numa comunidade de leitores, um espaço onde as leituras sejam compartilhadas e em que haja respeito pelos limites e gostos dos participantes. Outro fator é a necessidade de se pensar na ampliação do repertório literário dessa comunidade. Por fim, para que essa ampliação do repertório aconteça, é preciso pensar em atividades sistemáticas, em que se cumpra a tarefa da escola de formar o leitor literário, ou seja, aquele que vá dar continuidade a esse processo pela sua vida afora (COSSON, 2014, p. 186). O projeto aqui relatado foi pensado a partir dessa perspectiva.

Mas é importante também assumir uma postura crítica com relação ao desenvolvimento deste projeto. Podemos apontar um aspecto falho na prática pedagógica relatada, que foi a não abordagem dos aspectos visuais do livro em questão. Em livros como esse, configurados para o público infantil e juvenil, aspectos multimodais são muitíssimo relevantes. Trata-se de obra produzida com a finalidade de também seduzir pela imagem e não apenas pelo texto verbal. Reconhecemos a dificuldade dos professores da educação brasileira para um trabalho com aspectos multimodais das obras literárias, já que a formação básica dos cursos de graduação que formam esses professores geralmente não têm disciplinas que colaborem para esse trabalho. Fica, então, registrada aqui a necessidade de que os cursos de Pedagogia e similares incluam em suas grades curriculares disciplinas que possam complementar a formação docente, com assuntos do âmbito da semiótica e que incluam reflexões sobre os conceitos de múltiplas linguagens ou multimodalidade, teorias da imagem, da cor e outros aspectos que apontem para a interpretação da linguagem visual.

Vale ressaltar também que o trabalho com o objeto livro ficou prejudicado pelo uso de cópias xerográficas em preto e branco, em lugar da edição original. Sabemos que a relação do leitor com o objeto original, com boa encadernação, papel de boa qualidade, 
ilustrações coloridas e todos os demais aspectos que o constituem, provoca no leitor sensações bem diferentes do que a leitura de cópias reproduzidas. Enfim, este trabalho também reflete a precariedade com a qual o professorado se defronta cotidianamente, principalmente no sistema público de ensino, com falta de material adequado para o desenvolvimento do seu trabalho.

\section{Sessão de produção de relatos}

Nesta seção do artigo, relatamos como a professora avançou da leitura para a produção textual com a turma. Para tanto, tomou-se como ponto de partida o relato de memória "O touro e a vó Luiza", que constava também do livro didático de língua portuguesa do $3^{\circ}$ ano, utilizado na escola: Mundo amigo: letramento e alfabetização na escola (CASSIANO, 2011). O trabalho foi bastante sistemático, envolvendo os dois suportes: o livro literário e o livro didático.

Ainda que de maneira breve, a professora certificou-se de que a escolarização do texto literário pelo livro didático se deu de maneira minimamente adequada. De acordo com Soares (2011), os autores de livros didáticos, muitas vezes, escolarizam o texto literário de tal forma que eles perdem aspectos de sua literariedade: alterações de paragrafação, de estruturas linguísticas, de vocabulário, de contexto textual - relações com a ilustração; sem contar os exercícios propostos aos alunos, que muitas vezes se resumem à mera localização de informações, metalinguagem ou são moralizantes. Não era o caso do livro didático em questão.

O trabalho iniciou-se pelo texto no livro didático. Primeiro, a leitura silenciosa e, depois, leitura em voz alta. Ao final do texto, a professora destacou a referência bibliográfica e questionou os alunos se eles sabiam o significado daquela informação que aparece ao final de muitos textos. Alguns comentaram que se tratava do autor do texto. Outros se mantiveram em silêncio. Diante disso, a professora explicou à turma que a referência bibliográfica fornece as informações sobre o suporte original dos textos. Assim, a turma pegou o livro literário e conferiu a referência bibliográfica. Desta forma, os alunos compreenderam melhor o sentido das informações que aparecem ao final dos 
textos nos livros didáticos. Para muitos, foi uma grande descoberta. Os dois textos foram então comparados, confirmando que muita coisa do original foi mantida.

As atividades propostas no livro didático foram então realizadas. Neste momento, os alunos puderam realizar por escrito atividades que vinham fazendo oralmente, até então. Como tarefa, a professora pediu que conversassem com os pais sobre alguma experiência vivida com os avós, para irem pensando no texto que produziriam. A família ajudaria as crianças a pensar numa situação específica, vivida com o avô ou avó, a qual eles gostariam de registrar em forma de relato, como fez o autor do livro.

Na sétima semana, a proposta foi que a turma produzisse um relato de memória, que envolvesse avô ou avó, inspirada pelas rodas de leitura e conversas que tiveram até então e também pela conversa que tiveram em casa. Antes de "colocarem a mão na massa", algumas discussões sobre as características do gênero foram retomadas e destacou-se a necessidade de organizar as ideias que orientariam a escrita. O assunto principal do texto que seria produzido foi discutido com cada aluno. Os alunos foram lembrados de que estes textos comporiam um livro para a turma, definindo assim quem seriam os leitores. "Era preciso caprichar", diziam os alunos. E eles capricharam. Enquanto escreviam, a professora aproveitava para tirar dúvidas e fazer comentários que ajudassem os alunos a pensar na melhor forma de colocarem as ideias no papel.

Escreveram os textos e a professora os levou para casa para ler. Nesse momento, fez uma avaliação mais pontual, registrando quais habilidades relativas à escrita o texto mostrava que os alunos dominavam e quais aquelas que precisariam de mais investimento. No que se refere ao gênero, a maioria da turma escreveu com as características que foram definidas. A descrição não apareceu tanto, mas todos conseguiram preservar a ideia do que é um relato de memória.

Depois dessa avaliação, a professora destacou alguns aspectos com a turma, chamando a atenção para o uso de letras maiúsculas, para a organização do texto em parágrafos, para a pontuação e para a coerência textual. Utilizando o acordo que fizeram para a correção de textos, fez as marcas combinadas onde eles deveriam rever o texto. A partir dessa avaliação, planejou a intervenção da próxima etapa. 
Na última semana do projeto, a professora explicou aos alunos que chegara a hora de ajustar o texto. Como eles já tinham o costume de escrever e revisar, isso não foi novidade para a turma. As marcas no texto já indicavam onde os alunos deveriam intervir. Cada aspecto linguístico foi representado por um símbolo: uso de letras maiúsculas, parágrafos, pontuação, concordância verbal e ortografia.

Para essa revisão, os alunos foram organizados em grupos, para que a professora colocasse juntos aqueles alunos que precisariam de uma ajuda mais sistemática para ajustar o texto. Aqueles com mais autonomia foram acabando a reescrita, com ajuda dos colegas do grupo, e partiram logo para a ilustração do texto, a outra atividade desta etapa. Os alunos que apresentaram dificuldade foram acompanhados de perto pela professora, pois o texto demandava alterações mais substanciais.

Ao final da reescrita e ilustração dos textos, os alunos leram para os colegas seus relatos de memória e apresentaram os desenhos. Logo após, decidiram qual seria o título do livro. Depois de algumas sugestões, optou-se por Vovô e Vovó: Memórias dos alunos do $3^{\circ}$ ano.

Neste segundo momento do projeto, o foco maior foi a produção do texto. Assim como para a leitura, algumas estratégias específicas foram utilizadas, inspiradas em Girotto e Rovoredo (2011). A primeira delas foi situar o projeto e o contexto, quando relembraram todos os relatos de memória que já haviam lido até então, e as crianças foram incentivadas também a buscar na família outros subsídios para suas produções. No momento da produção, buscaram determinar quais os parâmetros da situação de comunicação: quem era o emissor, quem eram os possíveis interlocutores, quais eram os objetivos do texto, qual seria o conteúdo da narrativa, e, além disso, qual era o formato e os principais elementos que comporiam o texto. Após estas reflexões, as crianças escreveram individualmente e livremente seus textos, que passaram por uma avaliação, uma forma de confrontação das escritas, em que muitos elementos fundamentais foram observados e destacados e, em seguida, no momento da reescrita, as crianças analisaram suas produções com os apontamentos feitos pela professora, fazendo a releitura de seus textos. Nessa etapa, os alunos produziram as versões finais e as apresentaram para os colegas para uma melhor apreciação e valorização do trabalho. 
Com o material produzido pelas crianças, a professora digitou os textos e digitalizou as imagens para a organização do livro que ficaria no "cantinho de leitura" da sala de aula.

Essa etapa do projeto também apresentou alguns limites que não podemos deixar de evidenciar. Um deles foi a mediação do professor no processo de produção de textos. A estratégia adotada pela professora, de fazer marcas ou símbolos nos textos escritos pelos alunos é uma estratégia que contribui pouco para o avanço na habilidade com a escrita. Conforme pontuado em Geraldi (2015, p. 170) "trabalhar entre o sabido e o potencial é a forma de mediação do professor, que se torna assim um coautor dos textos de seus alunos: faz junto e ambos avançam em suas capacidades de produção de novos textos." Infelizmente, as próprias condições de uma turma em processo de alfabetização dificultam essa mediação necessária com todos os alunos e levaram a professora, neste caso, a privilegiar um grupo menor de crianças com uma mediação mais sistemática. Os demais alunos apenas fizeram correções de modo mais tradicional e mecânico.

As ilustrações dos textos também seguiram essa linha. A professora precisava que a turma se mantivesse ocupada enquanto auxiliava aquele grupo menor. A ilustração dos próprios textos se prestou muito mais a isso e não se configurou como uma atividade tão planejada, orientada e fundamentada teoricamente. A própria conclusão do projeto, ficando a cargo da professora a finalização do livro, também se constitui num limite da experiência e necessita ser pontuada. Os alunos poderiam ter participado mais ativamente também nesta etapa.

\section{Algumas considerações sobre a prática}

Há certo tempo se requeria que o aluno fosse alfabetizado no primeiro ano de escolarização, com pena de retenção, caso isso não acontecesse. Hoje, defende-se a ideia da continuidade e progressão das aprendizagens no ciclo de alfabetização, na perspectiva da formação do leitor e produtor de textos. Nessa direção, a opção por trabalhar a partir de projetos de letramento literário parece-nos bastante coerente e afinada com as discussões atuais em torno da alfabetização e do letramento escolar. Até pouco tempo, as capacidades privilegiadas pela escola eram as de codificação e decodificação do 
escrito. Hoje, espera-se que as crianças estejam plenamente alfabetizadas aos oito anos de idade.

De certo, essa cobrança representa uma sobrecarga para o professor alfabetizador, quando é sabido que inúmeros fatores extraescolares estão diretamente associados com o sucesso ou o fracasso do processo de alfabetização. No entanto, quando se opta por colocar o livro literário como ferramenta principal no trabalho com a língua, acreditamos que sejam demarcadas certas concepções em torno da linguagem, leitura e escrita, contribuindo para que o objetivo de alfabetizar letrando seja alcançado. Assim, aposta-se num ensino da língua materna em torno de práticas sociais de leitura e escrita, proporcionando aos alunos a inserção em práticas culturais dentro do espaço escolar. Dessa forma, as crianças desenvolveram capacidades por meio de atividades que Ihes faziam sentido. Ademais, a professora buscou contemplar e analisar os caminhos percorridos pelas crianças em relação à socioconstrução de conhecimentos, tomando os gêneros do discurso como objeto de ensino.

Ao enfocar o relato de memória como meio para a apropriação da linguagem escrita, para a aprendizagem do ato de ler e escrever, as crianças deverão utilizar esse gênero como ele aparece na sociedade. As rodas de conversa e leitura levaram as crianças à compreensão e reflexão dos textos, como forma de garantir o domínio da língua falada e escrita.

De acordo com o relato da professora, trabalhar com o livro Histórias de avô e avó Ihe trouxe uma satisfação muito grande, por dois motivos principais. O primeiro deles se refere ao desenvolvimento da turma. Quando terminou o projeto, estava no meio do ano letivo, mas já era possível observar o quanto os alunos tinham avançado desde o diagnóstico inicial. As observações diretas em todas as etapas não deixavam dúvidas. Mais especificamente, este trabalho lhe mostrou a importância do planejamento para o sucesso de uma prática pedagógica. Quando o projeto foi organizado, ela já conhecia o livro literário e o livro didático da turma. Então, as atividades foram planejadas e as intervenções foram bem mais ricas naquele ano. Ela pôde ter clareza de ter ampliado os horizontes textuais dos alunos, quando buscou assumir uma postura frente à leitura literária que proporcionasse aos meninos o prazer na leitura; mais do que isso, que levasse os alunos a uma atitude "responsiva-ativa" em relação ao texto, na qual cada 
aluno, cada sujeito histórico e social pôde construir seus sentidos subjetivos para o que lia ou ouvia, concordando ou discordando dos autores, refletindo sobre outros pontos de vista e sobre relações que poderiam ser estabelecidas com seus contextos sociais imediatos.

O segundo motivo alegado pela professora é mais afetivo. Talvez porque, de acordo com o seu depoimento, tenha tido uma relação muito forte com seus avós na infância: "Eles foram pessoas que me marcaram muito e este projeto me fez lembrar vários momentos vividos com eles. Senti isso também com as crianças e os textos que elas produziram. As escritas trouxeram marcas muito fortes da relação de amor e carinho que elas tinham com os vovôs e vovós."

Infelizmente, muitas pesquisas ainda indicam que poucas e as mais básicas capacidades de leitura e escrita têm sido ensinadas, avaliadas e cobradas pela escola. É como se a escola tivesse parado no tempo; geralmente, os alunos só participam de práticas que envolvem a leitura em voz alta (para avaliar a fluência) e respondem a um questionário em que se deve localizar e copiar informações do texto (para avaliar a compreensão). Há ainda muito poucas práticas de produção de textos, principalmente nos anos iniciais da alfabetização, principalmente porque se espera que o aluno só esteja apto a escrever textos, depois de alfabetizado. Nas palavras da professora, "foi exatamente para não ampliar as estatísticas que contabilizam os resultados negativos de práticas dessa natureza, e com o objetivo precípuo de possibilitar aos alunos o desenvolvimento de outras habilidades de leitura e também de escrita, que este projeto foi organizado".

A avaliação da turma foi pautada num processo de reflexão e análise constantes, por meio de diagnóstico e monitoramento em cada momento do projeto. Foram feitos registros, planejadas intervenções. Possibilitou-se que as crianças se apropriassem da linguagem escrita de maneira prática; nas palavras de Girotto e Revoredo (2011, p. 210) “aprende-se a ler, lendo; aprende-se a escrever, escrevendo; e também a ler, escrevendo e a escrever, lendo."

Retomando a epígrafe que abre este artigo, queremos reiterar que este trabalho de letramento literário na escola teve em vista levar os alunos a se apropriarem de 
práticas sociais de leitura e escrita que devem acompanhá-los pela vida afora, tornandoos mais autônomos na leitura literária na vida adulta.

Encerramos com um trecho do depoimento da professora da turma: "como alfabetizadora, não só este projeto, mas todos que desenvolvi ao longo do ano, tendo o livro literário como mote, evidenciaram a possibilidade de a escola formar leitores e produtores de texto proficientes e eficazes; de a leitura poder e dever significar mais na escola e alimentar a essência das crianças. Afinal, é pela leitura que se descobre o mundo."

\section{Referências}

BAKHTIN, Mikhail. Estética da criação verbal. São Paulo: Martins fontes, 1992.

BAKHTIN, Mikhail. Para uma filosofia do ato responsável. São Carlos: Pedro e João editores, 2010.

BRASIL. Ministério da Educação. Secretaria de Educação Fundamental. Parâmetros Curriculares Nacionais: introdução aos parâmetros curriculares nacionais. Brasília: MEC/SFE, 1997.

CASSIANO, Célia. Mundo amigo: letramento e alfabetização. São Paulo: Editora SM, 2011.

CORRÊA, Hércules Tolêdo. Roda de leitura. In: FRADE, Isabel C. Alves da Silva et al. Glossário Ceale: termos de alfabetização, leitura e escrita para educadores. Belo Horizonte: UFMG/Faculdade de Educação, 2014. p. 291-292. 
COSSON, Rildo. Letramento literário: teoria e prática. São Paulo: Cortez, 2006.

COSSON, Rildo. Letramento literário. In: FRADE, Isabel C. Alves da Silva et al. Glossário Ceale: termos de alfabetização, leitura e escrita para educadores. Belo Horizonte: UFMG/Faculdade de Educação, 2014. p. 185-186.

FRADE, Isabel C. Alves da Silva et al. Glossário Ceale: termos de alfabetização, leitura e escrita para educadores. Belo Horizonte: UFMG/Faculdade de Educação, 2014.

FERREIRO, Emília. Reflexões sobre alfabetização. São Paulo: Cortez, 2011.

GERALDI, João Wanderley. Mediação pedagógica no processo de produção de textos. In: GERALDI, João Wanderley. A aula como acontecimento. São Carlos: Pedro e João Editores, 2015. p. 165-182.

GIROTTO, Cyntia Graziella Guizelim; REVOREDO, Mariana. Narrativas míticas e a apropriação da leitura escrita literária: uma proposição prática. In: SOUZA, Renata Junqueira de e FEBA, Berta Lúcia Tagliari (Orgs.). Leitura literária na escola: reflexões e propostas na perspectiva do letramento. São Paulo: Mercado de Letras, 2011. p. 183-212.

INSTITUTO BRASILEIRO DE GEOGRAFIA E ESTATÍSTICA. Censo demográfico 2010: educação e deslocamento: dados da amostra. Rio de Janeiro: IBGE, 2010.

INSTITUTO PAULO MONTENEGRO. Indicador de alfabetismo funcional: principais resultados. São Paulo, 2011.

KLEIMAN, Angela. Os estudos de letramento e a formação do professor de língua materna. Linguagem em (dis)curso. v. 8, n. 3, p. 487-517, set./dez., 2008.

LETRIA, José Jorge. Os animais fantásticos. São Paulo. Salamandra, 2011. MACHADO, Ana Maria. De carta em carta. São Paulo. Salamandra, 2011.

NESTROVSKI, Arthur. Histórias de avô e de avó. São Paulo: Companhia das Letrinhas, 1998.

PAULINO, Graça. Letramento literário: cânones estéticos e cânones escolares. In: Das leituras ao letramento literário. Belo Horizonte: FAE/UFMG; Pelotas: EDGUFPEL, 2010. p. 154-166.

ROJO, Roxane. Letramento e capacidades de leitura para a cidadania. São Paulo: SEE: ENP, 2004. Texto apresentado em Congresso realizado em maio de 2004.

Disponível em:

<http://www.academia.edu/1387699/Letramento_e_capacidades_de_leitura_para_a_cida dania>. Acesso em 5 de maio de 2017.

SOARES, Magda. A escolarização da literatura infantil e juvenil. In: EVANGELISTA, Aracy Alves Martins; BRANDÃO, Heliana Maria Brina; MACHADO, Maria Zélia Versiani (Orgs.). 
Escolarização da leitura literária. $2^{\text {a }}$ ed., $3^{\text {a }}$ reimp. Belo Horizonte: Autêntica, 2011.

SOUZA, Renata Junqueira de e FEBA, Berta Lúcia Tagliari (Orgs.). Leitura literária na escola: reflexões e propostas na perspectiva do letramento. São Paulo: Mercado de Letras, 2011.

WEBB, Steve. Viviana, a rainha do pijama. São Paulo: Salamandra, 2011. 